\title{
MIGRAZIONI: DIZIONARIO SOCIO-PASTORALE
}

\author{
Graziano Battistella (curatore) \\ Editora San Paolo, Cinisello Balsamo (MI), 2010, 1152 p.
}

Migrazioni - Dizionario socio-pastorale é uma obra que contém desafios entrelaçados. De um lado, a complexidade da tipologia do dicionário e, de outro, aquela do fenômeno migratório. E isso na perspectiva sociopastoral. Estes são alguns dos múltiplos desafios que o organizador teve que enfrentar na realização deste volume. O organizador, Graziano Battistella, scalabriniano, foi diretor e professor do Scalabrini International Migration Institute (SIMI) em Roma (Itália). Atualmente é diretor do Scalabrini Migration Center (SMC) em Quezon City (Filipinas). Na realização deste dicionário, ele contou com a colaboração de 123 autores. O resultado são 156 verbetes, redigidos num total de 1152 páginas.

A ideia de realizar um dicionário sociopastoral começou a circular entre os Centros de Estudos Migratórios da Congregação Scalabriniana no início de 1980 (p. XII). No final da mesma década, o Center for Migration Studies, de New York, tentou concretizar esta intuição, mas sem conseguir levá-la a termo. O dicionário Migrazioni iniciou a ser planejado dentro da história do SIMI, criado em 2000 e com sede em Roma. A maioria dos verbetes do dicionário foi redigida até dezembro de 2008, enquanto alguns outros foram completados até meados de 2009. Esta delimitação temporal é importante para possibilitar uma aproximação ao conteúdo numa perspectiva correta, sem querer encontrar referências e atualizações ligadas a acontecimentos ou publicações posteriores a esta data.

O dicionário apresenta uma dúplice análise: social e pastoral. A análise social está presente em, aproximadamente, 50 verbetes. Nessa perspectiva, alguns apresentam os vários momentos do processo migratório, outros, as diferentes dimensões que concernem à vida dos migrantes. Alguns verbetes estudam as tipologias de migrantes. Uma atenção especial é dada aos direitos dos migrantes e instrumentos de proteção dos migrantes e refugiados. Nesta ótica sociológica não fica de fora a dimensão teórica 
das migrações, enfocando as principais teorias migratórias e seus aspectos fundamentais, como globalização, demografia, etnicidade, redes sociais, ligação entre migração e desenvolvimento (p. XIII). Por estas razões, o dicionário pode ser utilizado como instrumento introdutório ao conhecimento social das migrações.

A análise pastoral é mais articulada. Os verbetes se referem ao mundo bíblico, à história da Igreja e de sua ação pastoral em favor dos migrantes, entre outros. No horizonte bíblico encontram-se 20 verbetes. A história de Israel apresenta-se, assim, resgatada numa dimensão que lhe é constitutiva: nomadismo, experiência de estar em terra estrangeira, retorno, diáspora, etc. Alguns verbetes abrangem o Antigo Testamento, outros o Novo. Apresentam-se personagens bíblicas que podem se tornar ícones migratórios. O próprio Jesus é resgatado nessa perspectiva. Desde o início da história da Igreja, na época patrística, percebe-se uma atenção específica voltada aos migrantes. Também são resgatados personagens chave da Igreja na época das migrações massivas do século XIX. Nesse âmbito, o organizador esclarece que privilegia personagens italianas pelo fato do dicionário ser editado no idioma italiano (p. XIV). Retoma-se a voz dos papas na ótica das migrações. Apresentam-se os ensinamentos da Igreja, destacando quatro documentos principais: Exsul familia, Nemo Est, Chiesa e mobilitá umana e Erga migrantes caritas Christi. A perspectiva pastoral aflora, também, nos verbetes dedicados à pastoral de grupos específicos, como também em temáticas transversais. Outra especificidade é a apresentação da experiência de algumas igrejas particularmente interessadas pelo fenômeno migratório, por isso são citadas algumas Conferências Episcopais. Num olhar mais amplo, destaca-se a perspectiva continental, como, por exemplo, a da Conferência Episcopal LatinoAmericana (CELAM). A dimensão ética, apesar de não ser desenvolvida num único verbete, está presente em outros, tais como, bem comum, dignidade humana, justiça, etc. Existe também referência à teologia das migrações.

Se estas são as duas perspectivas deste dicionário, vale a pena apresentar a estrutura geral. Na Apresentação (p. V-XV), o organizador expõe, de maneira sintética, alguns dados gerais sobre as migrações, a origem e originalidade do dicionário, sua estrutura, as análises sob os enfoques social e pastoral e alguns agradecimentos. Em seguida, apresenta o conselho científico, enumera os autores e os tradutores (p. XVII-XXIII), traz o "elenco das abreviações e siglas" (p. XXV-XXXII) e, na sequência, em ordem alfabética, são dispostos os 153 verbetes. No final, o leitor se 
depara com o "índice dos documentos pontifícios e da Santa Sé" (p. 10931097), o "índice das entidades e dos instrumentos internacionais relativos aos migrantes" (p. 1098-1105), o "índice dos nomes bíblicos" (p. 11061107), o "índice dos nomes" (p. 1108-1114) e o "índice dos verbetes" (p. 1115-1118). Por último, estão anexados os dados a respeito das migrações internacionais atualizados em 2010, graças à autorização das Nações Unidas (Department of Economic and Social Affairs. Population Division).

Cada verbete apresenta o sumário, o desenvolvimento da temática, uma importante referência bibliográfica e as conexões com outros termos apresentados no dicionário. Os 156 verbetes se dividem em curtos (43), médios (53) e longos (60). Esta última categoria compreende os que têm mais de 4 mil palavras.

Os 123 autores têm diferentes experiências e formação. A riqueza aparece observando a proveniência geográfica, os cargos que ocupam e as instituições de pertença ou com as quais colaboraram. É natural que uma parte esteja ligada às instituições italianas, mas a totalidade apresenta experiência internacional. Entre as instituições e universidades italianas de pertença dos autores, lembramos: Università degli Studi di Milano; Istituto di Ricerche sulla Popolazione e le Politiche Sociali; Consiglio Nazionale delle Ricerche (Roma); Istituto Universitário Europeo (Firenze); Università Cattolica del Sacro Cuore (Milano); Università Ca' Foscari di Venezia; Università di Roma la Sapienza; Centro Studi Politica Internazionale - CeSPI (Roma); Università degli Studi di Palermo. Entre as universidades pontificias, todas localizadas em Roma, encontramos: Università Pontificia Salesiana; Pontificia Università Urbaniana; Pontificia Università Gregoriana; Pontificia Università Lateranense e Accademia Alfonsiana.

Outros autores estão ligados a entidades internacionais. A título de exemplo, lembramos algumas: Centre for Migration Policy and Society (COMPAS), University of Oxford; Department of Sociology, University of Toronto; Marymount Manhattan College (New York); International Migration Programme, International Labour Organization (Genebra); United Nations High Commissioner for Refugees (UNHCR); All Souls College, Oxford; Research and Publications Division, International Organization for Migration, Genebra; University of California at Davis; Princeton University; University of Delaware; Department of Geography, University College London; Georgetown University; School of the Environment and Society, Swansea University, United Kingdom; Catholic 
Theological Union (Chicago); Department of Geography, University of Sussex - United Kingdom; Calumet College of St. Joseph, Whiting, Indiana; National University of Singapore; Centre d'Étude des Relations Internationales de Sciences-Po (CERI) - Paris.

Paolo Parise

Diretor do Centro de Estudos Migratórios 